УДК 2-75:37.01

DOI https://doi.org/10.32838/2709-2933/2020.1/01

\title{
Горбань О.В.
}

Київський університет імені Бориса Грінченка

\section{ФІЛОСОФСЬКА ПАРАДИГМА СУЧАСНОЇ ОСВІТИ В ПОСТІНДУСТРІАЛЬНОМУ СУСПІЛЬСТВІ}

\begin{abstract}
У даній статті актуалізується питання визначення філософської парадигми сучасної освіти в його постнекласичних формах як основи соціокультурної модернізаиї̈ постіндустріального суспільства.

Зокрема, аналізу піддається сучасна ситуачія постнекласичної парадигми освіти, яка з одного боку, відновлює класичний підхід до системних знань, а з іншого - об'єднує його з принципово новими світоглядними тенденціями, які відображають як принципи нової некласичної наукової парадигми, так і сочіальні модуси сучасного людства. Найважливіші концептуальні підстави постнекласичної парадигми освіти пов 'язані з суб 'єктно-суб 'єктними, креативно-інтеграційними і синергетичними підходами до освіти. Зроблений висновок про перспективність подальшого напряму дослідження проблеми, яким слід вважати обтрунтування необхідності інтерпретаиї̈ філософсько-освітньої парадигми як основного предмету філософських досліджень.
\end{abstract}

Ключові слова: освіта, світогляд, парадигма, постіндустріальне суспільство, принципи реформування освіти, постнекласична освіта.

Постановка проблеми. Складність і різноманітність сучасного світу характеризується стратегічною нестійкістю, всебічне дослідження якої $\epsilon$ прерогативою виключно філософії. Рефлексія сучасності - одне з найважливіших філософських завдань.

Сучасна філософія бачить процес пізнання як найважливішу подію буття, як єдність розуму та інтуїції, раціонального та ірраціонального, монізму і плюралізму, об'єктивного і суб'єктивного, загального і конкретного. Тому затребуваність філософії сьогодні визначається як завданнями орієнтації в надзвичайно мінливому світі, так і формуванням нових світоглядних парадигм. Ці ж тенденції проявляються i по відношенню до культури, з якою нерозривно пов'язана освіта.

Загальнофілософські знання самі по собі залишаться лише абстрактною схемою, якщо вони не будуть збагачені знаннями, що відносяться до інших наук і сфер людської діяльності. Причому кожна 3 наук розглядає проблеми освіти в своїй логіці, в своєму специфічному ракурсі. Однак тільки філософія, на наш погляд, дозволяє рефлексувати процес освіти в його цілісності і системності. Саме філософський рівень дослідження дозволяє розглядати освіту як цілісність і взаємозумовленість окремих напрямків і структур- них компонентів, а також виділяє соціокультурну функціональність даної сфери знань.

Філософія освіти на сьогоднішній день формується як базисна теоретична основа трансформаційних процесів в сфері освіти в постіндустріальному суспільстві. Вона відображає соціальну значимість філософії для функціонування і розвитку системи освіти як елемента соціокультурного життя сучасного суспільства.

Найважливішим напрямом досліджень сучасної філософії освіти виступає пошук сучасної філософсько-освітньої парадигми як постнекласичної парадигми освіти, що грунтується на суб'єктно-суб'єктних, креативно-інтеграційних та синергетичних підходах до освітнього процесу, сприйнятті і втіленні знань відповідно до інноваційних потреб сучасності.

Ступінь розробки проблеми. Розробка проблем філософії освіти бере свій початок в ідеях Просвітництва, які здійснили істотний вплив на творчість Я. Коменського, Й. Песталоцці, Й. Гербарта. Розвиваючись в ідеях Й. Фіхте і Г. Гегеля, структуралізація наукового знання знайшла форму транслювання його в навчальних процеcax, привівши орієнтацію освіти до самопізнання, 3 акцентом на самоформування особистості.

Сучасні підходи у філософії освіти виходять 3 проблеми кризи класичної системи освіти. 
У працях сучасних дослідників Дж. Дьюї, Б. Гершунського, Х. Тхагапсоєва, М. Романенко, А. Тягло, Н. Розова, Е. Гусинського, Ю. Турчанінова, Т. Воропай, С. Клепко та ряду інших піднімаються питання предмету філософії освіти, іiі парадигмальних підстав, ролі й місця філософського знання як базисної основи освітніх процесів в постіндустріальному суспільстві [1-3].

Мета дослідження полягає в розгляді філософської парадигми сучасної освіти в іiі постнекласичних формах як основи соціокультурної модернізації постіндустріального суспільства.

Виклад основного матеріалу. Філософія освіти, асимілююча всі ці знання в їх найбільш узагальненому, концептуальному вигляді, являє собою, по суті, науково обгрунтовану i суспільно визнану наукову парадигму, яка б означала «визнані всіма наукові досягнення, які протягом певного часу дають модель постановки проблем і їх рішень науковому співтовариству» [4, с.11].

Слід погодитися $з$ думкою М. Романенко, що узагальнююче-рефлексивна i проектно-спрямовуюча функції філософії освіти по відношенню до розвитку освітньої системи проявляються в тому, що вона створює ії парадигму - змістовно i формально інтегровану сукупність найбільш загальних системоутворюючих ідей і принципів, які визначають теоретико-методологічні і світоглядні основи освітньої практики і педагогічної теорії. Філософсько-освітня парадигма $є$ квінтесенцією філософсько-освітнього знання - саме на цьому рівні досягається його цілісність і взаємозумовленість окремих напрямів і структурних компонентів, а також кристалізується соціокультурна функціональність даної сфери знань. Зі змістовної сторони філософсько-освітня парадигма грунтується на узагальненні основних підходів до вирішення свого проблемного поля у всіх його аспектах, за винятком внутрішніх проблем гносеологічного характеру. Таким чином, філософсько-освітня парадигма в концентрованому вигляді відображає соціальну значимість філософії освіти для функціонування і розвитку системи освіти, і в більш широкому плані - як аспекту соціокультурного життя суспільства $[5,112]$.

Сучасна парадигма освіти знаходить свої концептуальні засади в некласичних підходах, які втілюють нераціональні, а точніше не обмежені раціональним методом пізнання і включають в себе емоційну, психологічну, підсвідому і чуттєву сфери людської свідомості, породжуючи асоціативні, інтуїтивні, інтегративні та інтерактивні форми переживання, а не знання істини.
Сьогодні ми маємо підстави говорити про постнекласичну парадигму освіти, яка, з одного боку, відновлює класичний підхід до системних знань, а з іншого - об'єднує його з принципово новими світоглядними тенденціями, які відображають як принципи нової некласичної наукової парадигми, так і соціальні модуси сучасного людства.

На думку Ю. Шабанової, найважливіші концептуальні підстави постнекласичної парадигми освіти пов'язані з суб'єктно-суб' єктними, креативно-інтеграційними і синергетичними підходами до освіти [6, 117].

Одна 3 поширених рис постнекласичної освіти пов'язана 3 тенденцією антропологізаціі знання як форми інформації не тільки для людини, але і відкритої людиною, застосовуваної людиною і рефлексованої людиною. Антропологічний аспект виступає в сучасній некласичній парадигмі як підстава для зміни класичної об'єкт-суб' єктної форми процесів навчання на суб'єкт-суб'єктні, де будь-який учасник просвітницького простору сприймається як рівноправний, самоцінний $\mathrm{i}$ активний суб'єкт. Позбавлення об'єкт-суб' єктної опозиції не є знищенням їх соціальних ролей. Внаслідок цього зростає і роль відповідальності за об'єктивність знань не тільки в того, хто навчає, а й у того, хто навчається.

Зміни відбуваються і в принципах мотивації просвітницького процесу постнекласичної парадигми. Вона змінюється під впливом культурносоціальних установок сучасного суспільства, які містять в собі альтернативне, мінливе різноманіття розвитку. Це породжує принципи толерантної поліконцептуальності і комунікативної культури та відповідно, в просвітницькій парадигмі формує засоби для порушення тотального існування єдиних підходів і незмінності знань. Наслідком таких підходів стає поліфонія методик, методологій, концептуальних засад та форм навчання, що існують на засадах діалогічності і взаємодоповнення. Так ознакою нової просвітницької парадигми $\epsilon$ шлях діалогу, розмови, співіснування, яке відкриває можливості відкриття множинності смислів, значень, конотацій, які не підпорядковані єдиній концептуальній домінанті. У цьому контексті знання набувають ознак плюральності, інтердисциплінарності, рухливості, а їх осягнення відповідно формується різноманітними формами активізації свідомості, яка не обмежується раціонально-системною тотальністю. Завдяки цьому кожен учасник просвітницького процесу має можливість обирати найбільш близькі для себе форми 
і методи навчання, що значно покращує його продуктивність.

Досить затребуваними на сучасному освітянському просторі стають методологічні основи синергетичного підходу, як моделі саморозвитку людини в швидкоплинному світі. Цей концепт допомагає визначити вже не тільки суто сцієнтистські підходи в осягненні знань, а звернутися до антропологічного питання самовизначення людини в світі. В контексті синергетичної методології відбувається подолання наукоцентричних світоглядних установок, здійснюється переорієнтація 3 техногенних технологій до антропософських концепцій, в яких цілісне знання людини вже не відповідає лінійному типу часів класичного мислення.

Наслідком такого підходу $є$ нелінійний тип мислення, який значно збагачує палітру пізнавальних можливостей в постнекласичній парадигмі освіти. Особливістю нелінійного мислення $€$ його нестійкість і відкритість, яка значно сприяє здійсненню самоорганізації і збільшенню кількості виникнення нових структур. Так, кризовий стан системи нелінійного мислення, яке має значно більше шансів на виникнення, ніж в межах лінійного мислення, закономірно стає потенцією виникнення евристичного підходу до світобачення. Деструкція є обов'язковою умовою виникнення нової впорядкованості.

Такий підхід відповідає сучасному рівню постіндустріальної цивілізації і їі досягнень культури і пізнання, для яких характерні інтеграція наук, мистецтв, змішання стилів життя; де формується новий тип мислення, в якому на чільне місце виходить «філософія нестабільності» [7], де «оборотні, стійкі і повторювані в повноті буття процеси розглядаються вже як окремий випадок на тлі концептуально продуманої проблеми народження, розвитку і зникнення нових форм» [8]; де домінуючою рисою мислення стає асоціативність і найважливішого значення набуває випадок, а також уміння побачити і зрозуміти нове, всупереч стереотипам (тобто бачити не тільки закономірне та типове, але конкретне й індивідуальне).

Тепер особливого значення набуває не стільки рух до фундаментального визначення або поняття, скільки сам рух думки як подія в системі інтересів і цінностей суб'єкта в його теперішньому житті. Така філософія дозволяє зближувати внутрішні і зовнішні світи, включати в картину універсуму унікальні події, пов'язані з творенням, творчістю. Мова, таким чином, йде «про деяку розширену онтологію раціонально незбагненних явищ»
(М.К. Мамардашвілі), в тому числі і про онтологію істини, що включає в себе і свідомість осягаючого іiі суб'єкта.

За такої філософії освіта стає орієнтована не так на зовнішні об'єкти, до яких потрібно звернути увагу суб'єкта (учня), а на саму людину, мінливу в своєму осягненні світу і змінюючу світ в цьому осягненні, на особистість, здатну стати унікальним джерелом творчості і продуктивної діяльності.

Нова парадигма заснована вже не на відтворенні минулого знання, а на готовності його використання в нових, часто заздалегідь не регламентованих, ситуаціях. Вона готує до «невизначеного майбутнього», але зберігає від старої системи заданість технологій реагування в цих ситуаціях. Раніше були задані ситуації і способи реагування в цих ситуаціях, тепер освоюється деякий набір технологій реагування на безліч подібних ситуацій 3 нечітко заданими межами. Тип особистості тоді формується, як і раніше, орієнтований на стабільність соціальної поведінки, але вже з акцентом на стабільність динаміки його поведінки.

Сучасна освіта апелює до відносності ціннісних критеріїв. Тим самим, вона орієнтує кожне нове покоління на мінливість життєвого процесу і рефлексії з його приводу, короткочасність його ситуаційних колізій, способів і критеріїв їх вирішення i, відповідно, на вміння необхідним чином на них реагувати.

Говорячи про зміну парадигми в освіті, слід зазначити про необхідність вдосконалення їі гуманістичної складової частини. Проблема ускладнюється тим, що наразі в системі освіти ми ще нерідко спостерігаємо безліч ознак освітянського, заснованого на класичному розумінні раціоналізму, підходу: сцієнтизм, диференціація знання в викладанні, ступінчастість підготовки, монологізм і авторитарність, утилітарність.

Таким чином, зміна світоглядної парадигми в філософії освіти продукує філософсько-освітнє знання, яке втілює в собі стратегічні ідеї підвищення ефективності освітнього процесу на основі його гуманізації, гуманітаризації, індивідуалізаціï, диференціації та демократизації на всіх етапах і у всіх ланках освіти [9-12]. Ці категорії можуть бути 3 достатньою повнотою осмислені лише на міждисциплінарному, інтегративному рівні. Саме тому й потрібен філософський, системний підхід до їх аналізу, характеристики i, в кінцевому підсумку, до їх синтезу.

Висновки. Характерною ознакою сучасної соціальної політики є пошуки і реалізація можли- 
вих варіантів реформ освіти. До того ж реформація спрямована не на зміну змістовних компонент освіти, а на формування нової освітньої стратегії, яка забезпечує не тільки високий професіоналізм, а й сприяє підвищенню рівня культурно-соціальної компетентності людини, як активного учасника всіх проявів життєвого світу. У зв'язку з цим можна говорити про нову, сучасну парадигму освіти, розуміючи під цим поняттям сукупність поглядів, принципів, уявлень, які формують методологічну основу організації освітньої діяльності, з певними онто-гносеологічними і антропо-аксіологічними установками, відповідно до вимог сучасності. Ці вимоги виходять, перш за все, з ситуації системної кризи класичної парадигми освіти, яка сьогодні демонструє неспроможність задовольнити запити соціуму в реалізації цілісної людини, гармонійно існуючої на всіх рівнях життєвого простору, не обмежуючись інформаційно-інтелектуальним і раціонально-сцієнтистським ракурсами. Так, соціокультурний контекст освіти, який виразився в посиленні їі ролі як першоджерела світо- глядних концептів, зумовлює процес кардинальних змін і, відповідно, парадигмальної установки освіти, яка протиставляється класичному погляду.

Суть такого підходу полягає в констатації думки про те, що в сучасних умовах конкурують три парадигмальні типи освіти. Один з них спирається на традиції Просвітництва i, по суті, в сучасних умовах являє собою відживаючий атавізм. Другий відповідає реаліям індустріального суспільства і займає наразі домінуючі позиції в рамках сучасної цивілізації, проте вже не може забезпечити подальшого розвитку освіти в умовах загальносистемних соціальних змін. Третій тип це нова філософсько-освітня парадигма, яка формується разом 3 розвитком постіндустріального суспільства i, по суті, являє собою завтрашній день освіти і всього соціуму.

Найбільш перспективним подальшим напрямом дослідження проблеми, слід вважати обгрунтування необхідності інтерпретації філософсько-освітньої парадигми як основного предмета філософських досліджень.

Список літератури:

1. Гершунский Б.С. Философия образования для XXI века: в поисках практико-ориентированных образовательных концепций. М., 1998.

2. Гусинский Э.Н., Турчанинова Ю.И. Введение в философию образования. Учебное пособие. М., 2000.

3. Клепко С.Ф. Українська царина філософії освіти. Практична філософія. 2001. № 1. С. 197-211.

4. Кун Т. Структура научных революций. М.: Мысль, 1977.

5. Романенко М.І. Гуманізація освіти: концептуальні проблеми та практичний досвід. Дніпропетровськ: ДОІППО, 2001.

6. Шабанова Ю.О. Сучасна парадигма освіти. Вісник ДНУ. Серія «Філософія. Соціологія. Політологія». Дніпропетровськ: ДНУ, 2007. С. 117-121.

7. Пригожин И.Р. Философия нестабильности. Вопросы философии 1991. №6. С. 48-52.

8. Мамардашвили М.К. Классический и неклассический идеалы рациональности. Гл. 1. // www. philosophy.ru/ library.

9. Философия образования: «Круглый стол» журнала «Педагогика». Педагогика. 1995. № 4. С. 3-28.

10. Философия образования: состояние, проблемы и перспективы (материалы «круглого стола»). Вопросы философии. 1995. № 11. С. 3-24.

11. Філософія освіти в сучасній Україні: Матеріали Всеукраїнської науково-практичної конференції «Філософія освіти та стан ії̈ розробки в Україні». К., 1997. 254 с.

12. Философия культура и образование (материалы «круглого стола»). Вопросы философии. 1999. № 3. C. 3-54. 


\section{ФИЛОСОФСКАЯ ПАРАДИГМА СОВРЕМЕННОГО ОБРАЗОВАНИЯ В ПОСТИНДУСТРИАЛЬНОМ ОБЩЕСТВЕ}

В данной статье актуализируется вопрос определения философской парадигмы современного образования в его постнеклассических формах как основы соџиокультурной модернизачии постиндустриального общества.

В частности, анализу подвергается современная ситуация постнеклассической парадигмы образования, которая с одной стороны, возобновляет классический подход к системным знаниям, а с другой - объединяет его с принципиально новыми мировоззренческими тенденциями, которые отражают как принципы новой неклассической научной парадигмы, так и сочиальные модусы современного человечества. Важнейшие кониептуальные основания постнеклассической парадигмы образования связаны с субъектно-субъектными, креативно-интеграчионными и синергетическими подходами к образованию. Сделан вывод о перспективности последующего направления исследования проблемы, которым следует считать обоснование необходимости интерпретаџии философско-образовательной парадигмы как основного предмета философских исследований.

Ключевые слова: образование, мировоззрение, парадигма, постиндустриальное общество, приниипы реформирования образования, постнеклассическое образование.

\section{PHILOSOPHICAL PARADIGM OF MODERN EDUCATION IN A POSTINDUSTRIAL SOCIETY}

In this article the question of determination of philosophical paradigm of modern education actualization in his postnonclassical forms as bases of socioculturale modernization of Postindustrial society. In particular, the modern situation of postnonclassical paradigm of education, which from one side, is exposed to the analysis, proceeds in classic approach to systems knowledge's, and from other-unites him with on principle new world views tendencies which reflect both principles of new nonclassical scientific paradigm and social modes of modern humanity. The major conceptual grounds of postnonclassical paradigm of education are related to subject-subjects, creative-integrations and synergetics approaches to education. A characteristic feature of modern social policy is the search for and implementation of possible options for educational reforms. In addition, the reform is not aimed at changing the content components of education but forming a new educational strategy that not only provides high professionalism, but also contributes to increase the level of cultural and social competence of the human being as an active participant in all manifestations of life. In this regard, we can talk about a new, modern paradigm of education by considering this concept as a set of views, principles, ideas that form the methodological basis for the organization of educational activities. A conclusion is done, about perspective of subsequent direction of research problems which follow to count the ground of necessity of interpretation of philosophical-educational paradigm as the basic article of philosophical researches.

Key words: education, world view, paradigm, Postindustrial society, principles of reformation of education, postnonclassical education. 